\title{
Bond Strength of composite repairs using flowable, conventional resins or the association of both
}

Resistência de união de reparos de resinas compostas usando resinas convencionais, fluidas, ou a associação de ambas
Taciana Marco Ferraz CANEPPELE

Assistant Professor - Department of Restorative Dentistry - São José dos Campos School of Dentistry - UNESP Univ. Estadual Paulista - São José dos Campos - Brazil

Raira Cruz CALAMARI Undergraduate Student - São José dos Campos School of Dentistry - UNESP Univ. Estadual Paulista - São José dos Campos - Brazil

Graziela Ribeiro BATISTA

Natalia Cortez GUTIERREZ

PhD students - Department of Restorative Dentistry - São José dos Campos School of Dentistry - UNESP Univ. Estadual Paulista - São José dos Campos - Brazil

Carlos Rocha Gomes TORRES

Assistant Professor - Department of Restorative Dentistry - São José dos Campos School of Dentistry - UNESP Univ. Estadual Paulista - São José dos Campos - Brazil

\section{Abstract}

Objectives: The aim of this in vitro study was to evaluate the effect on bond strength of composite repairs using flowable resin as an intermediate agent. Methods: Thirty truncated cones were fabricated with Grandio SO (VOCO) and were thermo-cycled for 5000 cycles for artificial aging. Specimen's surface was sandblasted with aluminum oxide, cleaned with air/water spray and conditioned with phosphoric acid for 15 s. One coat of Admira Bond Adhesive (VOCO) was applied and light cured for $20 \mathrm{~s}$. Specimens were divided into 3 groups according to the repairing material used $(\mathrm{n}=10)$ : Conventional Resin - Grandio SO (R), A thin layer of Flowable resin Grandio SO Heavy Flow + conventional Resin (FR), and Flowable resin (F). Over the original specimens, a sectional cone-shaped teflon matrix was hold in position and the cones were built according the groups described above. Other thirty specimens were built, 10 of each group, simulating a restoration without repair. Specimens were submitted to tensile stress in a universal testing machine. Data were recorded in $\mathrm{MPa}$ and evaluated with ANOVA, Tukey' s and non-paired " $t$ " tests. Results: ANOVA showed significant differences among groups in which repair was performed $(p<0.00)$. The results of Tukey's test for those groups were: $\mathrm{R}(19.89+$ 5.31)ab; F+R (14.49 + 5.59)a; F (20.91 + 3.99)b. The groups followed by the same letter did not show statistical differences. Non-paired " $\mathrm{t}$ " test showed that groups $\mathrm{R}$ and $\mathrm{F}$ repairs were similar to the correspondent groups simulating restoration without repair. Conclusions: The repair with conventional or flowable composite produced bond strength values similar to cohesive strength of the same materials. The use of a thin layer of flowable resin as an intermediate agent in composite repair decreased the bond strength when compared the same method for restoration.

\section{KEYWORD}

Composite repair; Bond strenght; Flowable resin.

\section{RESJMO}

Objetivos: O objetivo deste estudo in vitro foi avaliar o efeito sobre a resistência de união de reparos de compósitos com resina fluida como um agente intermediário. Métodos: Trinta cones truncados foram fabricados com Grandio SO (VOCO) e foram termociclados por 5.000 ciclos de envelhecimento artificial. A superfície da amostra foi jateada com óxido de alumínio, limpa com spray ar / água e condicionada com ácido fosfórico por $15 \mathrm{~s}$. Uma camada de adesivo (Admira - VOCO) foi aplicada e fotopolimerizada por $20 \mathrm{~s}$. As amostras foram divididas em três grupos de acordo com o material de reparo utilizado $(n=10)$ : resina convencional - Grandio $\mathrm{SO}(\mathrm{R})$, uma fina camada de resina flowable - Grandio SO Heavy Flow + Resina convencional (FR), e resina flowable $(\mathrm{F})$. Sobre espécimes originais, foi adaptada uma matriz, e os cones foram construídos de acordo com os grupos descritos acima. Trinta amostras foram construídos, 10 de cada grupo, simulando uma restauração sem reparos. As amostras foram submetidas ao Teste de tração em uma máquina universal de ensaios. Os dados foram registrados em MPa e avaliados com ANOVA, Tukey e teste " $\mathrm{t}$ " não pareado. Resultados: ANOVA mostrou diferenças significativas entre os grupos em que o reparo foi realizado $(\mathrm{p}<0,00)$. Os resultados do teste de Tukey para os grupos foram: $\mathrm{R}(19,89+5,31) \mathrm{ab} ; \mathrm{F}+$ $\mathrm{R}(14,49+5,59)$ a; $F(20,91+3,99)$ b. Os grupos seguidos pela mesma letra não apresentaram diferenças estatísticas. O Teste " $\mathrm{t}$ " não pareado de Student mostrou que as reparações dos grupos $\mathrm{R}$ e $\mathrm{F}$ foram semelhantes aos dos grupos correspondentes que simulam restauração sem reparos. Conclusões: $\mathrm{O}$ reparo com resina flowable ou convencional produziu níveis de resistência próximos a força coesiva dos mesmos materiais. A utilização de uma camada fina de resina fluida como um agente intermediário no reparo dos compósitos diminuiu a resistência de união, quando comparado o mesmo método para a restauração.

\section{Palavras-chave}

Reparo de compósitos, Resistência de união; Resina de baixa viscosidade. 


\section{INTRODUCTION}

Over the last few decades, significant improvements have been made in the field of resin composites. However, fractures and failures of composite restorations can still occur because of secondary caries and marginal defects $[1,2]$.

The traditional treatment of defective composite resin restorations includes removing and replacing the whole restoration. This approach is often accompanied by removal of tooth structure, expanding the prepared cavity, increasing the loss of sound tooth structure [3].

On the other hand, the repair of defective composite is more conservative and might increase the longevity of the restoration, preserving sound tooth structure, and also protecting the tooth from operative trauma [4]. This option is a more practical solution and allows the use of pre-existing restoration, if in acceptable condition [5].

Adhesion should not only be considered between material and the deantal tissues, but also the adhesion between two materials. The repair procedure might be more complicated in old resinbased composite restoration, because the amount of available unsaturated double bonds diminishes with aging [6,7]. Several changes occur to resinbased composites during aging process which could influence of the success of the repair procedure, such as water sorption, chemical degradation and leaching out of some of their components [8-10].

A variety of surface treatments and bonding agents has been used to improve the repair bond strength of resin composites [11,12]. Some of these techniques are applied for roughening the repaired surface, whereas others are based on attempts to improve the chemical bonding [13].

The treatments to roughen the surface include roughing with burs, acid etching with hydrofluoric or phosphoric acid, and air-borne particle abrasion $[12,14]$.

Unfilled resins have been usually suggested as intermediate agents for composite repair, promoting wetting of the roughened substrate by penetration of resin monomers into surface micro-cracks $[15,16]$. Modifications in dentin bonding agents formulations led to the introduction of filled adhesives [17]. By the addition of fillers to the resin matrix with different concentration, a thicker layer of adhesive is produced, and can behave as a stress-absorbing liner between the restorative material and the dental tissues [18-20]. Similarly, flowable composites have been proposed as intermediate, stressrelieving agents in direct composite restorations [21-24]. Thus, they could stand the early polymerization shrinkage stress of the overlying resin composite and subsequently absorb the shock produced by funcional load, thermal strains, and occlusal forces [25].

An optimal adaptation to both cavity floor and margins has been reported for filled adhesives and flowable composites [24,26-28]. In theory, these concepts could be applied in composite repairing procedures. The use of a low viscosity filled material as an intermediate agent in a restoration repair may result in an improvement of the interfacial quality and the adehsive performance of the repairing composite, if compared to traditional bonding resins.

The oxygen-inhibited layer is always present when composite resin is polymerized in air. It is composed of unreacted monomers and improves adhesion between materials [29,30]. Because of this layer, bond strength of incrementally built-up composites on the fresh resin composite is similar to the cohesive strength of the material [31]. The amount of available unreacted monomers decreases with aging [7]. Thus, the chemical bond between the fresh resin and the aged resin is not reliable.

Repairs of composites restorations are generally performed months or years after baseline. During this time, the restoration is exposed to the oral environment, resulting in water sorption of and the cease of free-radical activity[4]. In this context, the age of restoration to be repaired has an important role in the bond strength of resin composite repair [32].

In laboratory studies, the aging of composite resin has been simulated by different methods, including water storage [13,33], immersion in citric acid [12,34] and thermocycling $[1,2,12,34]$. Thermal cycling is often used for aging of composite resins in composite repairing tests. This method involves subjecting the specimens to extreme temperatures. High or elevated temperatures are know to weaken the composites. In addition to the effect of weakening on the physicochemical properties of the composites, the changes in temperature can reduce the number of unreacted double bonds on the surface or within the composite, which can affect the compositecomposite repair strength [12].

Thus, the aim of this study was to evaluate the effect of flowable composite as an intermediary, or fill in the repair of composite resin restorations. The null hypothesis tested was that there is no significant difference between the use or not of flowable composites for repair of composite resin.

\section{Material And Method}

Sixty truncated cone shaped specimens (botton-4 $\mathrm{mm}$; top $-2 \mathrm{~mm}$; height $-4 \mathrm{~mm}$ ) were prepared with 
Grandio SO (Voco, Cuxhaven, Germany) composite resin using increments of $2 \mathrm{~mm}$.

Thirty specimens were submitted to artificial aging (5000 thermal cycles 50 to $55 \mathrm{oC}, 30 \mathrm{~s}$ dwell time). After the thermal cycling the top of the specimens were sandblasted with aluminum oxide, cleaned with air/water spray and conditioned with phosphoric acid for $15 \mathrm{~s}$. After that, one coat of Admira Bond Adhesive (VOCO) was applied and light cured for $20 \mathrm{~s}$. Over the original specimens, a sectional Teflon matrix with a cone-shape was hold, and the composite used to repair was applied.

The specimens were divided into three groups according to viscosity of the composite resin used:

Group R - The composite Grandio SO was applied in increments of $2 \mathrm{~mm}$, each photocured for $40 \mathrm{~s}$;

Group FR - A thin layer of approximately $0.5 \mathrm{~mm}$ of the composite Grandio SO Heavy Flow (Voco, Cuxhaven, Germany) was applied and photocured for $40 \mathrm{~s}$. Over that, other layers with $2 \mathrm{~mm}$ thickness of Grandio SO of conventional viscosity was applied and photocured for $40 \mathrm{~s}$;

Group F - The composite Grandio SO Heavy Flow was applied in increments of $2 \mathrm{~mm}$, each one photocured for 40s.

\section{TAble 1 - Materials used}

\begin{tabular}{|c|c|c|c|}
\hline Material & Manufacturer & Composition & Lot \\
\hline $\begin{array}{l}\text { Grandio } \\
\text { SO }\end{array}$ & $\begin{array}{l}\text { Voco/ Cuxhaven/ } \\
\text { Germany }\end{array}$ & $\begin{array}{c}\text { Resin Matrix: } \\
\text { Bis-GMA, BisEMA, } \\
\text { TEGDMA, CQ, } \\
\text { Amine, BHT. } \\
\text { Inorganic } \\
\text { Content: nanofillers } \\
\text { of } \mathrm{SiO}_{2}: 20-40 \mathrm{~nm} \text {; } \\
\text { glass ceramic: } 1 \mu \mathrm{m} \text {. } \\
\text { Fill content: } 89 \% \\
\text { in weight and } 73 \% \text { in } \\
\text { volume. }\end{array}$ & 1029391 \\
\hline $\begin{array}{c}\text { Grandio } \\
\text { so Heavy } \\
\text { Flow }\end{array}$ & $\begin{array}{l}\text { Voco/ Cuxhaven/ } \\
\text { Germany }\end{array}$ & $\begin{array}{c}\text { Resin Matrix: } \\
\text { Bis-GMA, BisEMA, } \\
\text { TEGDMA, HDDMA, } \\
\text { CQ, Amine, BHT. } \\
\text { Inorganic } \\
\text { Content: nanofillers } \\
\text { of } \mathrm{SiO}_{2}: 20-40 \mathrm{~nm} \text {; } \\
\text { glass ceramic: } 1 \mu \mathrm{m} \text {. } \\
\text { Fill content: } 83 \% \\
\text { in weight and } 68 \% \text { in } \\
\text { volume. }\end{array}$ & 1123233 \\
\hline $\begin{array}{l}\text { Admira } \\
\text { Bond } \\
\text { (two-step } \\
\text { etch-and- } \\
\text { rinse) }\end{array}$ & $\begin{array}{l}\text { Voco/ Cuxhaven/ } \\
\text { Germany }\end{array}$ & $\begin{array}{l}\text { Etchant: } 36 \% \\
\text { phosphoric acid } \\
\text { Adhesive: acetone, } \\
\text { bonding ormocer, } \\
\text { dimethacrylates, } \\
\text { initiators, stabilizer }\end{array}$ & 1025303 \\
\hline
\end{tabular}

Over the remaining 30 specimens, truncated cone shaped specimens were built up immediately after the first cone were performed, varying the viscosity of composite, simulating a restoration with no repairing procedure.

Figure 1 presents the groups arrangement and Figure 2 shows the experimental design.

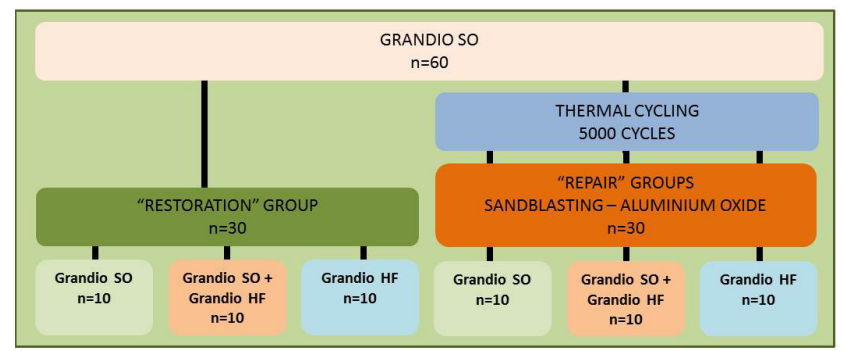

Figure 1 - Groups arrangement

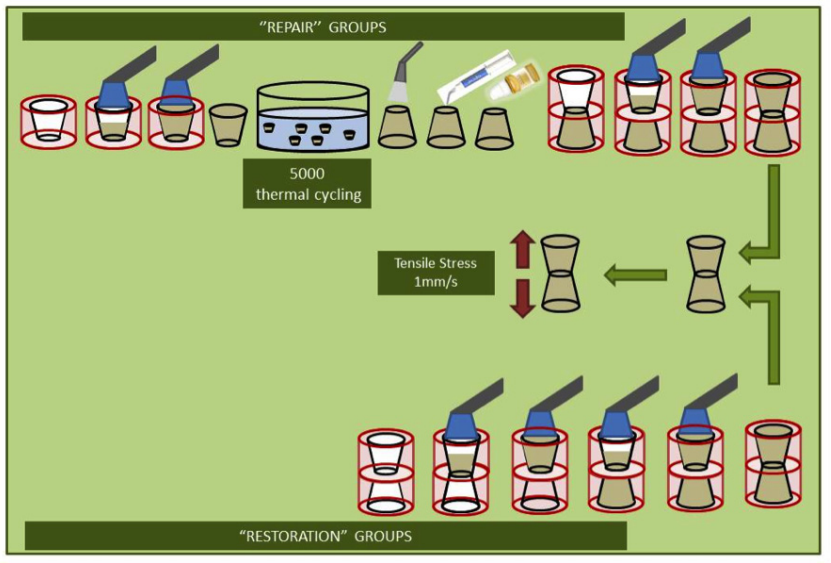

Figure 2 - Study Design

All specimens were stored in deionized water for $24 \mathrm{~h}$ and then were submitted to tensile stress in a universal testing machine (DL-200 MF, Emic, Pinhais, PR, Brazil) with a cross-speed of $1 \mathrm{~mm} / \mathrm{s}$. The data were recorded in MPa.

To better characterize the composites used in this study and also help understand the results, some properties of the materials were measured. For this, specimen was made a $40 \times 6 \times 2 \mathrm{~mm}$ of each resin. The elastic modulus was measured by the device Sonelastic (ATCP, Sao Carlos, Brazil) and the microhardness by Knoop Hardness (FM-700, FutureTech, Equilam, Tokyo, Japan). The polymerization shrinkage was measured by the device AccuVol (Bisco, Illinois, USA) and polymerization stress by universal testing machine (DL-200 MF, Emic, Pinhais, PR, Brazil). For all properties, three measurements were performed and the average value of them was considered. 


\section{Statistical analysis}

After analyzing the bond strength data for normality of data distribuition (Kolmogorov-Smirnov test), a two-way ANOVA was applied with bond strength as the dependent variable, and viscosity of resin and treatment (restoration or repair) as factors. The Tukey's test was used for post-hoc multiple comparisons. A series of t-tests for independent samples was applied to assess the differences in bond strength between restoration and repair procedures, within each viscosity resin group. All analyses were processed using Statistica Software. The level of significance was set at $\mathrm{p}<0.05$.

\section{RESULTS}

Table 2 presents the Resin features.

\section{TABLE 2 - Resin Features}

\begin{tabular}{c|c|c}
\hline Properties & Conventional & Flowable \\
\hline Elastic Modulus (GPa) & 21.62 & 12.85 \\
\hline Microhardness (HK) & 93.19 & 40.27 \\
\hline Polymerization Shrinkage (\%) & 2.56 & 3.66 \\
\hline Polymerization stress (N) & 3.51 & 6.22 \\
\hline
\end{tabular}

Results of tensile bond strength testing are summarized in Table 3. The two-way ANOVA revealed that only the type of treatment (repair or restoration $)(\mathrm{p}<0.001)$ had a significant influence on tensile bond strength.

\section{Table 3 - Tensile bond StRength of the tested GROUPS}

\begin{tabular}{c|c|c|c}
\hline Groups & $\begin{array}{c}\text { Repair } \\
(\mathbf{M P a})\end{array}$ & $\begin{array}{c}\text { Restoration } \\
(\mathbf{M P a})\end{array}$ & $\begin{array}{c}\text { \% of } \\
\text { cohesive } \\
\text { strength }\end{array}$ \\
\hline Grandio SO (R) & $19.89 \pm 5.31^{\mathrm{A} 1}$ & $23.50 \pm 5.81^{\mathrm{A} 1}$ & 75 \\
\hline $\begin{array}{c}\text { Grandio HF } \\
+ \text { Grandio SO } \\
(\mathrm{FR})\end{array}$ & $14.49 \pm 5.59^{\mathrm{A} 1}$ & $23.09 \pm 4.82^{\mathrm{A} 2}$ & 53 \\
\hline Grandio HF (F) & $20.91 \pm 3.99^{\mathrm{A} 1}$ & $22.66 \pm 6.14^{\mathrm{A} 2}$ & 80 \\
\hline
\end{tabular}

Superscripts letters show differences within the same column $(\mathrm{p}<$ $0.05)$, numbers within the same rows $(\mathrm{p}<0.05)$.

Comparable results between the two types of treatment (repair or restoration) were obtained by using conventional resin or Flowable resin only. When flowable and conventional resin were used together, the repair was weaker than the restoration.

\section{Discussion}

A finding of this investigation was the statistically inferior adhesive performance in tensile bond strength for thin flowable composite layer as intermediate agent in composite repair. Thus, the null hypothesis is rejected.

The strength values of the repaired specimens in this study ranged between 53 and 80 percent in comparison with nonrepaired specimens (Table 3). The obtained range was consisted with findings in the literature $[35,36]$. The results confirmed that strength values of repaired restorations are lower than those of the cohesive bond strength (Restoration groups).

Flowable composites are presently used in a wide range of applications: as liners in Class I [23], II $[24,26], \mathrm{V}$ [28] restorations, as pit and fissure sealants [37], core build-up materials, for tunnel and preventive resin restorations. The application of flowable composite as the sole repair material after coating the surface with adhesive has also proposed [35].

Our results showed 80 percent of the bond strength value of repair only with flowable resin compared to restoration. Low-viscosity was claimed to promote a better adaptation than highly viscous composite materials to the aged, roughened, adhesive coated resin surface, thus increasing retention via micromechanical interlocking. However, their reduced mechanical and physical properties when compared with traditional hybrid composites [38] could represent a concern when repairing restorations in high stressbearing areas. The flowable composite used in our study has a high filler content (Table 1), which could have reduced this problem. Using flowable resins as intermediate agents prior to layering a repairing hybrid composite may overcome these clinical limitations of some flowable resins, taking advantage of their stressabsorbing ability and avoiding a direct exposure to occlusal load.

The combination of flowable and conventional resin to perform the repairs showed the lowest bond strength values compared to values obtained when the materials were used separately. Due to differences in mechanical properties of materials, the use of a thin layer of resin flow between two bodies of conventional resin on an aged surface (repair group), caused a weakening of the set, resulting in low values of adhesive strength. On the other hand, previous studies 
using flowable composite as intermediate agent have achieved satisfactory values of bond strength $[39,40]$.

The use of sandblasting as a manner to promote the surface roughness of the aged resin was efficient, since in two groups, the bond strength values were higher than $70 \%$ of the cohesive strength of the assembly. Previous studies also showed effectiveness of this type of surface treatment to repair composite resin [41].

An important aspect regarding this study is the inclusion a positive control groups (Restoration Groups), which shows the cohesive strength. The positive control presents the repair potential relative to the cohesive strength of the material.

Repairs of composite restorations are generally performed months or years after baseline. Several changes occur to resin-based composites during the aging process that can influence the success of the repairing procedure, such as water sorption, chemical degradation, and leaching out of some constituents [13]. On this account, the age of the restoration to be repaired plays a fundamental role in the bond strength of composite repairs [32].

Thermal cycling is a method of providing laboratory simulations of oral conditions. This test involves subjecting specimens to extreme temperatures. Several factors affect the thermal cycling on the bond strength of adhesive systems, including temperature settings, dwell time, and the number of the cycles. According Amaral el al. [42], the number of cycles is considered to be the most influential factor of all.

Although according to ISO standards, 500 thermocycles in water temperatures between $5 \mathrm{oC}$ and $55 \mathrm{oC}$ is considered to be an appropriate test for aging dental materials, results from previous study showed that 500 thermocycles did not significantly affect the bond strength of composite to dentin surfaces [43].

According to Özcan et al. [12], the effect of aging conditions on the bond strength of resin composite to composite showed that 5000 thermocycles were more effective in the degradation of the composite tested than other aging methods. Thus, in the present study, it was performed 5000 thermocycles to aging the resin composite before the repair.

\section{Conclusion}

Repairing with conventional or flowable composites produced bond strength values similar to the cohesive strength of the corresponding materials. The use of a thin layer of flowable resin as an intermediate agent in composite repair decreased the bond strength when compared the same method for restoration.

\section{References}

1. Magni E, Ferrari M, Papacchini F, Hickel R, Ilie N. Influence of ozone on the composite-to-composite bond. Clin Oral Investig. 2011 Apr;15(2):249-56.

2. Yaman BC, Efes BG, Dorter C, Gomec Y, Erdilek D, Yazicioglu O. Microleakage of repaired class V silorane and nano-hybrid composite restorations after preparation with erbium:yttrium-aluminum-garnet laser and diamond bur. Lasers Med Sci. 2011 Mar;26(2):163-70.

3. Gordan VV. Clinical evaluation of replacement of class $\mathrm{V}$ resin based composite restorations. J Dent. 2001 Sep;29(7):485-8.

4. Rathke A, Tymina Y, Haller B. Effect of different surface treatments on the composite-composite repair bond strength. Clin Oral Investig. 2009 Sep;13(3):317-23.

5. Bonstein T, Garlapo D, Donarummo J, Jr., Bush PJ. Evaluation of varied repair protocols applied to aged composite resin. J Adhes Dent. 2005 Spring;7(1):41-9.

6. Ruyter IE. Unpolymerized surface layers on sealants. Acta Odontol Scand. 1981;39(1):27-32.

7. Vankerckhoven H, Lambrechts $\mathrm{P}$, van Beylen M, Davidson CL, Vanherle G. Unreacted methacrylate groups on the surfaces of composite resins. J Dent Res. 1982 Jun;61(6):7915.

8. Attin T, Buchalla W, Kielbassa AM, Helwig E. Curing shrinkage and volumetric changes of resin-modified

glass ionomer restorative materials. Dent Mater. 1995 Nov;11(6):359-62.

9. Tarumi H, Torii M, Tsuchitani Y. Relationship between particle size of barium glass filler and water sorption of lightcured composite resin. Dent Mater J. 1995 Jun;14(1):37-44.

10. Suzuki S, Ori T, Saimi Y. Effects of filler composition on flexibility of microfilled resin composite. J Biomed Mater Res B Appl Biomater. 2005 Jul;74(1):547-52.

11. Swift EJ, Jr., LeValley BD, Boyer DB. Evaluation of new methods for composite repair. Dent Mater. 1992 Nov;8(6):362-5.

12. Ozcan M, Barbosa SH, Melo RM, Galhano GA, Bottino MA. Effect of surface conditioning methods on the microtensile bond strength of resin composite to composite after aging conditions. Dent Mater. 2007 Oct;23(10):1276-82.

13. Fawzy AS, El-Askary FS, Amer MA. Effect of surface treatments on the tensile bond strength of repaired wateraged anterior restorative micro-fine hybrid resin composite. J Dent. 2008 Dec;36(12):969-76.

14. Swift EJ, Jr., Brodeur C, Cvitko E, Pires JA. Treatment of composite surfaces for indirect bonding. Dent Mater. 1992 May;8(3):193-6.

15. Matsumura H, Hisamatsu N, Atsuta M. Effect of unfilled resins and a silane primer on bonding between layers of a light-activated composite resin veneering material. J Prosthet Dent. 1995 Apr;73(4):386-91.

16. Brosh $\mathrm{T}$, Pilo R, Bichacho N, Blutstein R. Effect of 
combinations of surface treatments and bonding agents on the bond strength of repaired composites. J Prosthet Dent. $1997 \mathrm{Feb} ; 77(2): 122-6$.

17. Labella R, Lambrechts P, Van Meerbeek B, Vanherle G. Polymerization shrinkage and elasticity of flowable composites and filled adhesives. Dent Mater. 1999 Mar;15(2):128-37.

18. Feilzer AJ, De Gee AJ, Davidson CL. Quantitative determination of stress reduction by flow in composite restorations. Dent Mater. 1990 Jul;6(3):167-71.

19. Davidson CL, Feilzer AJ. Polymerization shrinkage and polymerization shrinkage stress in polymer-based restoratives. J Dent. 1997 Nov;25(6):435-40.

20. Choi KK, Condon JR, Ferracane JL. The effects of adhesive thickness on polymerization contraction stress of composite. J Dent Res. 2000 Mar;79(3):812-7.

21. Montes MA, de Goes MF, da Cunha MR, Soares AB. A morphological and tensile bond strength evaluation of an unfilled adhesive with low-viscosity composites and a filled adhesive in one and two coats. J Dent. 2001 Aug;29(6):43541.

22. Ausiello P, Apicella A, Davidson CL. Effect of adhesive layer properties on stress distribution in composite restorations--a 3D finite element analysis. Dent Mater. 2002 Jun;18(4):295303.

23. Miguez PA, Pereira PN, Foxton RM, Walter R, Nunes MF, Swift EJ, Jr. Effects of flowable resin on bond strength and gap formation in Class I restorations. Dent Mater. 2004 Nov;20(9):839-45.

24. Olmez A, Oztas N, Bodur H. The effect of flowable resin composite on microleakage and internal voids in class II composite restorations. Oper Dent. 2004 NovDec;29(6):713-9.

25. Kemp-Scholte CM, Davidson CL. Marginal integrity related to bond strength and strain capacity of composite resin restorative systems. J Prosthet Dent. 1990 Dec;64(6):658-64.

26. da cunha Mello FS, Feilzer AJ, de Gee AJ, Davidson CL. Sealing ability of eight resin bonding systems in a Class II restoration after mechanical fatiguing. Dent Mater. 1997 Nov;13(6):372-6.

27. Opdam NJ, Roeters JJ, de Boer T, Pesschier D, Bronkhorst E. Voids and porosities in class I micropreparations filled with various resin composites. Oper Dent. 2003 JanFeb;28(1):9-14.

28. Li Q, Jepsen S, Albers HK, Eberhard J. Flowable materials as an intermediate layer could improve the marginal and internal adaptation of composite restorations in Class-Vcavities. Dent Mater. 2006 Mar;22(3):250-7.

29. Shawkat ES, Shortall AC, Addison O, Palin WM. Oxygen inhibition and incremental layer bond strengths of resin composites. Dent Mater. 2009 Nov;25(11):1338-46.

30. Ghivari S, Chandak M, Manvar N. Role of oxygen inhibited layer on shear bond strength of composites. J Conserv Dent. Jan;13(1):39-41.

31. Boyer DB, Chan KC, Torney DL. The strength of multilayer and repaired composite resin. J Prosthet Dent. 1978 Jan;39(1):63-7.

32. Soderholm KJ, Roberts MJ. Variables influencing the repair strength of dental composites. Scand J Dent Res. 1991 Apr;99(2):173-80.

33. Kimyai S, Mohammadi N, Navimipour EJ, Rikhtegaran S. Comparison of the effect of three mechanical surface treatments on the repair bond strength of a laboratory composite. Photomed Laser Surg. Oct;28 Suppl 2:S25-30.

34. Rinastiti M, Ozcan M, Siswomihardjo W, Busscher HJ. Effects of surface conditioning on repair bond strengths of non-aged and aged microhybrid, nanohybrid, and nanofilled composite resins. Clin Oral Investig. 2011 Oct;15(5):62533. doi: 10.1007/s00784-010-0426-6. Epub 2010 May 25.

35. Shen C, Mondragon E, Gordan VV, Mjor IA. The effect of mechanical undercuts on the strength of composite repair. J Am Dent Assoc. 2004 Oct;135(10):1406-12; quiz 67-8.

36. Soderholm KJ. Flexure strength of repaired dental composites. Scand J Dent Res. 1986 Aug;94(4):364-9.

37. Papacchini F, Goracci C, Sadek FT, Monticelli F, GarciaGodoy F, Ferrari M. Microtensile bond strength to ground enamel by glass-ionomers, resin-modified glass-ionomers, and resin composites used as pit and fissure sealants. J Dent. $2005 \mathrm{Jul} ; 33(6): 459-67$.

38. Clelland NL, Pagnotto MP, Kerby RE, Seghi RR. Relative wear of flowable and highly filled composite. J Prosthet Dent. 2005 Feb;93(2):153-7.

39. Papacchini F, Radovic I, Magni E, Goracci C, Monticelli F, Chieffi N, et al. Flowable composites as intermediate agents without adhesive application in resin composite repair. Am J Dent. 2008 Feb;21(1):53-8.

40. Frankenberger R, Kramer N, Ebert J, Lohbauer U, Kappel S, ten Weges $\mathrm{S}$, et al. Fatigue behavior of the resin-resin bond of partially replaced resin-based composite restorations. Am J Dent. 2003 Feb;16(1):17-22.

41. Loomans BA, Cardoso MV, Roeters FJ, Opdam NJ, De Munck J, Huysmans MC, et al. Is there one optimal repair technique for all composites? Dent Mater. 2011 Jul;27(7):701-9.

42. Amaral FL, Colucci V, Palma-Dibb RG, Corona SA. Assessment of in vitro methods used to promote adhesive interface degradation: a critical review. J Esthet Restor Dent. 2007;19(6):340-53; discussion 54.

43. Nikaido T, Kunzelmann KH, Chen H, Ogata M, Harada $\mathrm{N}$, Yamaguchi $\mathrm{S}$, et al. Evaluation of thermal cycling and mechanical loading on bond strength of a self-etching primer system to dentin. Dent Mater. 2002 May;18(3):269-75.

Received: 2013-01-16 Accepted: 2013-03-05

\section{Corresponding author}

Taciana Marco Ferraz Caneppele Department of Restorative Dentistry School of Dentistry of São José dos Campos Av. Eng. Francisco José Longo, $n^{\circ} 777$ - Jardim São Dimas São José dos Campos - SP, Brasil, CEP: 12245-000 e-mail: taciana@ict.unesp.br 